\title{
Population structure of the wood-decay fungus Trichaptum abietinum (J. Dicks.) Ryvarden in the Carpathian National Nature Park (Ukraine)
}

\author{
Sergey M. Boiko
}

Institute for Evolutionary Ecology, National Academy of Sciences of Ukraine, acad. Lebedev 37, Kyiv, 03143, Ukraine; Donetsk National University, 600-richya 21, Vinnytsia, 21021, Ukraine

e-mail:bsmbio@gmail.com

\begin{abstract}
This paper provides a list of intracellular isozyme systems of Trichaptum abietinum (J. Dicks.) Ryvarden (Basidiomycetes) that can be used for population studies. Population structure of the fungus within the Carpathian National Nature Park (CNNP) was established. Percent of polymorphic loci in general was $83.3 \%$. Groups of rare alleles were assigned $S o d^{88}$, $S o d^{138}, S d h 1^{91}$, and $E s t^{111}$. Calculated Wright's fixation index allowed establishing privilege of the heterozygotes on locus $A c p$ and homozygotes on locus Sod. The population of T. abietinum in the CNNP was in equilibrium state.
\end{abstract}

Key words: fungi, Basidiomycetes, population, genetic structure, isozymes, loci, alleles

\section{Introduction}

Wood for mushrooms is an unlimited source of carbon in their lifecycle. Generally, due to powerful fungal enzyme systems, the type of wood is not highly specific and fungi can develop on different substrates (Boddy et al. 2008). Saprotrophic Basidiomycota is able to break down plant litter and wood more rapidly than other fungi (Baldrian 2008; Osono \& Takeda 2006). Advanced enzyme systems of mushrooms can be used for biotechnological purposes and in population studies.

Defining the genetic structure of populations is a logical first step in studies of fungal population genetics because the genetic structure of a population reflects its potential to evolve (Hogberg et al. 1999). These issues can be solved using DNA technologies or such enzyme systems as genetic markers (Shnyreva et al. 2004; Mondini et al. 2009; Mishra et al. 2010). So, the analysis of molecular variance suggested that native strains of the Pleurotus species in Kenya are genetically more diverse than their exotic counterparts cultivated there now (Otieno et al. 2015). Genetic analyses of European and Japanese indoor populations showed that
Serpula lacrymans fungus spreads mainly sexually via basidiospores and significant genetic differentiation was detected among European populations of Heterobasidion annosum (Fr.) Bref. (Stenlid et al. 1994; Engh et al. 2010).

Co-dominant markers are, therefore, ideal for analyzing genotypic data of dikaryotic fungi. Isozymes remain a potent genetic marker in fungi that possess sufficient variation at allozyme loci (Siddiquee et al. 2007; Boiko 2015; Eichlerova et al. 2015) because it provides a fairly rapid and inexpensive alternative tool for the identification of some fungi species and for taxonomic studies (Bonde et al. 1993; Bragaloni et al. 1997; Annesi et al. 2003; Siddiquee et al. 2010).

One of the common species of fungi that colonize coniferous wood is Trichaptum abietinum (J. Dicks.) Ryvarden (Gorova 1980; Grand et al. 2009). T. abietinum is the most frequently observed white rot species, particularly in sapwood. Mycelium of T. abietinum colonizes from log surfaces and occupies large volumes of sapwood of Picea abies trees (Ovaskainen et al. 2013). However, widespread fungus does not indicate a deep knowledge of its biochemistry, genetics and ecology. 
Until now, there have only been a few publications of its genetic characteristics and possibilities of application (Jasalavich et al. 2000; Kauserud et al. 2003a; Zjawiony 2004; Udu-Ibiam et al. 2014). There are very few studies aiming at determining the population structure of the T. abietinum fungus and they are mostly related to Northern parts of the globe (Kauserud et al. 2003a, 2003b; Grand et al. 2009; Runnel et al. 2015). In this regard, the territory of Ukraine remains unexplored.

The purpose of this article was to analyze the population structure of T. abietinum located within boundaries of the Carpathian National Nature Park (CNNP).

\section{Material and methods}

The research was performed on dikaryotic T. abietinum cultures, isolated from basidiocarps growing on fir in the CNNP (Ivano-Frankivsk region of Ukraine). Isolation of pure dikaryotic cultures was performed according to generally accepted methods (Bilay 1982). Briefly, precleaned basidiocarp was cut into pieces $3 \times 3$ $\mathrm{mm}$, and transferred by a sterile mycological hook to $8 \% \mathrm{H}_{2} \mathrm{O}_{2}$ solution for 1-2 min. The $\mathrm{H}_{2} \mathrm{O}_{2}$-treated fragment was placed in a tube with potato agar, and, after the appearance of pure mycelium, re-inoculated on pure culture media. Isolates were cultured on a glucose-peptone liquid medium that was poured into $50 \mathrm{ml}$ Erlenmeyer flasks of $250 \mathrm{ml}$ capacity. The initial $\mathrm{pH}$ of the nutrient medium was 5.0. Cultivation occurred from 15-18 days.

The production of monokaryotic cultures was performed by the spore prints method. The purity of the spores and their affiliation to monosporous cultures was controlled by microscopy. Total number of dikaryotic and monokaryotic cultures was sixteen and eighty four, respectively.

The mycelium was washed and dried by vacuum filtration, then homogenized in a Tris-citrate buffer

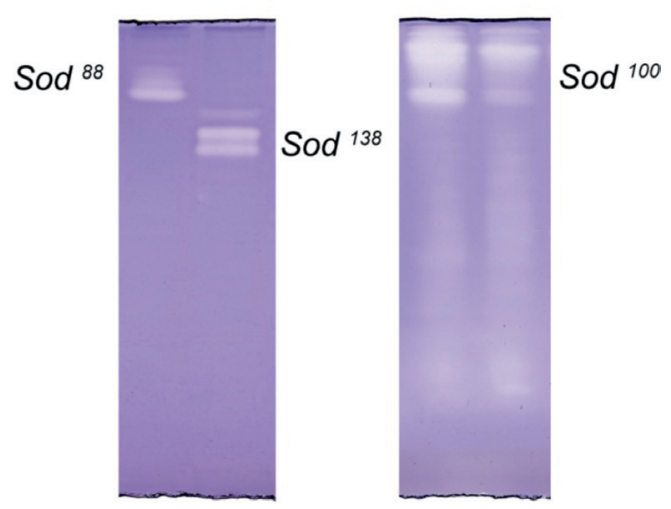

Fig. 1. Electrophoregram of superoxide dismutase allozymes of Trichaptum abietinum monokaryotic cultures system with subsequent filtration. The amount of total protein added into each well ranged from 40 to $60 \mu \mathrm{g}$. Electrophoretic separation of intracellular proteins was performed in $7.5 \%$ polyacrylamide gel using a Trisglycine buffer system (pH 8.3) (Hames 1998). Histochemical detection of activity zones was performed for the following enzyme systems: glutamate oxaloacetate transaminase (GOT, EC 2.6.1.1), esterase (EST, EC 3.1.1.1), acid phosphatase (ACP, EC 3.1.3.2), sorbitol dehydrogenase (SDH, EC 1.1.1.14), and superoxide dismutase (SOD, EC 1.15.1.1) (Manchenko 2003).

Genetic diversity of populations was characterized by the following indicators: polymorphic loci $(\mathrm{P})$, the average number of alleles per locus (A), effective number of alleles $\left(A_{E}\right)$, the number of alleles per polymorphic loci (Ap), Shannon diversity index (I), observed and expected average genetic heterozygosity per locus $\left(\mathrm{H}_{\mathrm{o}}\right.$ and $\left.\mathrm{H}_{\mathrm{e}}\right)$ and Wright's fixation index (Nei 1978). Data were analyzed using POPGENE 32 computer-based software (Yeh et al. 1999).

\section{Results}

For the calculation of T. abietinum population genetic diversity in the CNNP, six isozyme loci were detected in five studied enzyme systems. The analysis of intracellular superoxide dismutase in monokaryotic cultures revealed three loci specific to T. abietinum representatives (Fig. 1).

Generally, five enzyme systems were used in the experiment. Twelve allelic variants controlled by sixenzyme gene loci were established. A complete list of enzyme systems, their control and electrophoretic mobility are presented in Table 1.

Data analysis revealed that the number of polymorphic loci amounted to $83.3 \%$. Locus $S d h 2$, which was observed in $100 \%$ of studied T. abietinum cultures,
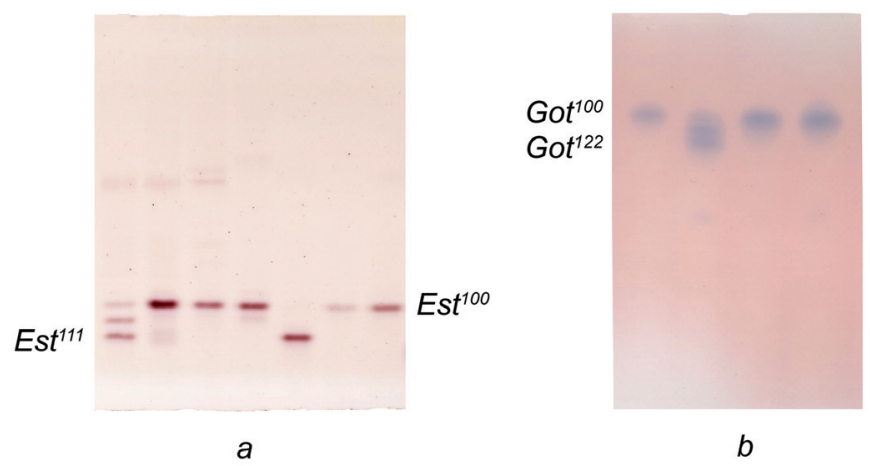

Fig. 2. Electrophoregram of allozymes of Trichaptum abietinum dikaryotic cultures

Explanations: $\mathrm{a}$ - esterase, $\mathrm{b}$ - glutamate oxaloacetate transaminase 
Table 1. Enzyme systems, loci and alleles with their electrophoretic mobility of Trichaptum abietinum

\begin{tabular}{lccc}
\hline \multicolumn{1}{c}{ Enzyme systems } & Loci & Alleles & $\begin{array}{c}\text { Rf (mobility relative } \\
\text { to dye marker) }\end{array}$ \\
\hline Glutamate oxaloacetate transaminase & Got & $1-100$ & 0.23 \\
Superoxide dismutase & & $2-122$ & 0.28 \\
& Sod & $1-88$ & 0.14 \\
& & $2-100$ & 0.06 \\
Sorbitol dehydrogenase & & $3-138$ & 0.16 \\
& & & 0.22 \\
& Sdh1 & $1-91$ & 0.26 \\
Esterase & & $2-100$ & 0.60 \\
Acid phosphatase & Sdh2 & $1-100$ & 0.66 \\
& & & 0.31 \\
& Est & $1-100$ & 0.35 \\
& & $2-111$ & 0.63 \\
& Acp & $1-100$ & 0.70 \\
& & & 0.19 \\
& & $2-137$ & 0.33 \\
& & & 0.26 \\
\hline
\end{tabular}

Table 2. Genetic diversity of Trichaptum abietinum in the Ivano-Frankivsk population Carpathian National Nature Park

\begin{tabular}{cccccc}
\hline Locus & $\mathrm{A}$ & $\mathrm{A}_{\mathrm{E}}$ & $\mathrm{I}$ & $\mathrm{H}_{\mathrm{O}}$ & $\mathrm{H}_{\mathrm{E}}$ \\
\hline Got & 2 & 1.3243 & 0.4101 & 0.2857 & 0.2637 \\
Est & 2 & 1.1529 & 0.2573 & 0.1429 & 0.1429 \\
Acp & 2 & 1.6897 & 0.5983 & 0.5714 & 0.4396 \\
Sdh1 & 2 & 1.1529 & 0.2573 & 0.1429 & 0.1429 \\
Sdh2 & 1 & 1.0000 & 0 & 0 & 0 \\
Sod & 3 & 1.3425 & 0.5091 & 0.1429 & 0.2747 \\
Average & 2 & 1.2771 & 0.3387 & 0.2143 & 0.2106 \\
\hline
\end{tabular}

Explanations: A - the number of alleles per locus, $A_{E}$ - the effective number of alleles per locus, $\mathrm{I}-$ Shannon diversity index, $\mathrm{H}_{\mathrm{O}}-$ observed heterozygosity per locus, $\mathrm{H}_{\mathrm{E}}-$ expected heterozygosity per locus

was monomorphic. Frequencies of allele isozymes are presented in Table 3.

The group of the most common alleles included: $\operatorname{Got}^{100}$ (one-band variant with Rf 0.23), Sod ${ }^{100}$ (two-band variants with $\mathrm{Rf} 0.06 ; 0.16$ ), $S d h 1^{100}$ (one-band variant with Rf 0.66), and $E s t^{100}$ (one-band variant with Rf 0.63); the group of rare alleles comprised: $\operatorname{Sod}^{88}$ (one-band variant with $\mathrm{Rf} 0.14$ ), Sod ${ }^{138}$ (two-band variants with $\mathrm{Rf}$
$0.22 ; 0.26$ ), $S d h l^{91}$ (one-band variant with Rf 0.60 ), and $E s t^{l l 1}$ (one-band variant with Rf 0.70) (Table 1; Fig. 2).

Genetic diversity indicators of the T. abietinum population in the Carpathian NNP are presented in Table 2. In general, loci of the studied enzyme systems were not distinguished by the number of alleles and had an average of two alleles per locus ( 2.2 per polymorphic loci).

Table 3. The allele frequency of Trichaptum abietinum from Ivano-Frankivsk population in the Carpathian National Nature Park

\begin{tabular}{ccccccc}
\hline \multirow{2}{*}{ Allele } & \multicolumn{7}{c}{ Loci } \\
\cline { 2 - 7 } & Got & Sod & Sdh1 & Sdh2 & Est & Acp \\
\hline 1 & 0.8571 & 0.0714 & 0.0714 & 1.0000 & 0.9286 & 0.2857 \\
2 & 0.1429 & 0.8571 & 0.9286 & - & 0.0714 & 0.7143 \\
3 & - & 0.0714 & - & - & - & - \\
\hline
\end{tabular}


Table 4. Wright's fixation index (Fis) according to the data from the Ivano-Frankivsk population Trichaptum abietinum in the Carpathian National Nature Park

\begin{tabular}{ccccccc}
\hline \multirow{2}{*}{ Allele } & \multicolumn{7}{c}{ Locus } \\
\cline { 2 - 7 } & Got & Est & Acp & Sdh1 & Sdh2 & Sod \\
\hline 1 & -0.1667 & -0.0769 & -0.4000 & -0.0769 & - & -0.0769 \\
2 & -0.1667 & -0.0769 & -0.4000 & -0.0769 & - & 1.0000 \\
3 & - & - & - & - & - & -0.0769 \\
Total & -0.1667 & -0.0769 & -0.4000 & -0.0769 & - & 0.4400 \\
\hline
\end{tabular}

\section{Discussion}

Experiments failed to establish a high level of polymorphism for the Schizophyllum commune fungus: five alleles per locus, on average (James et al. 1999), while for the Trichoderma harzianum fungus, this value did not exceed 1.57 (Siddiquee et al. 2010). The polymorphism value depends strongly on the used set of isozymes. Monomorphic loci greatly reduce this index, but on the other hand, can serve as species molecular markers (Annesi et al. 2003; Boiko 2015). More informative measure is the mean number of alleles per polymorphic locus because Ap is independent of the proportion of polymorphic loci (Berg et al. 1997). The number of alleles per polymorphic loci was 2.2 for our set of isozymes (Table 2). It is well known that the effective number of alleles maintained in a population is defined as the inverse of the homozygosity. As it can be seen, the effective number of alleles, generally, is below the average and is inherent to many ecosystems (Huang et al. 1998; Shnyreva et al. 2004; Xin Qian et al. 2013). On average, within population the effective number of alleles per locus is 1.27.

Shannon index of genetic diversity was the highest for Acp and Sod loci, and these values were 0.5983 and 0.5091 , respectively. The high Shannon index was also indirectly confirmed by high values of the effective allele number. The average heterozygosity indicating, which part of the population consisted of individuals that were heterozygous by studied markers had maximum values for the Acp locus. This demonstrated the important role of this locus in T. abietinum genetic diversity.

The investigated quantitative status of heterozygotes in the T. abietinum population made it possible to answer the question whether the population was in equilibrium state or not, according to the Hardy-Weinberg law. The impact of environmental factors can lead to significant changes in species genotype and, in extreme cases, can cause elimination of certain genes. According to the data, the average observed heterozygotes $(0.2143)$ was almost equal to the expected heterozygote value (0.2106), and this is evidence that the Hardy-Weinberg equation for the studied population was performed. Thus, the population of T. abietinum in the Carpathian NNP was in equilibrium state. Performance of panmictic conditions in this species was observed due to high outcrossing and abundance of T. abietinum in this region. Fennoscandian geographic populations of T. abietinum also satisfied Hardy-Weinberg conditions (Kauserud \& Schumacher 2003b).

Negative Wright's fixation index indicated a small excess of heterozygous genotypes for Got, Est, and $S d h 1$ loci, and domination of Acp (Table 4). This indicated an important role of the sexual process in the development of the T. abietinum population.

It is worth emphasizing a significant advantage of the homozygous state of the Sod locus. It is difficult to explain such "contrasting" indicators. Increasing the number of natural materials and expanding research area will probably answer this question in future.

\section{Conclusions}

The obtained data made it possible to determine that T. abietinum population in the Carpathian National Nature Park was in equilibrium state. The proposed enzyme systems are indicative and informative features to be used in population studies of the fungus. Polymorphic loci, as a whole, reached $83.3 \%$, and $\operatorname{Sod}^{88}$, $\operatorname{Sod}^{138}$, $S d h 1^{91}$, and $E s t^{111}$ were included in the group of rare alleles. The obtained Wright's fixation index allowed establishing prepotency of heterozygotes in the Acp locus and homozygotes - in the Sod locus of T. abietinum populations in the Carpathian NNP. An important role of the sexual process in the development of the T. abietinum population was established. 


\section{References}

Annesi T., Coppola R. \& Motta E. 2003. Isozyme analysis on some wood decay fungi. Journal of Plant Pathology 85: 87-90.

BALDRIAN P. 2008. Enzymes of saprotrophic basidiomycetes. In: L. Boddy, J. C. Frankland \& P. van West (eds.). Ecology of Saprotrophic Basidiomycetes, pp. 19-41. Academic Press, Amsterdam.

Berg E. E. \& Hamrick J. L. 1997. Quantification of genetic diversity at allozyme loci. Can. J. For. Res. 27: 415-424.

BILAY V. I. 1982. Metodyi eksperimentalnoy mikologii. Naukova dumka, Kyiv.

Boddy L., Frankland J. \& West P. 2008. Ecology of saprotrophic Basidiomycetes. 372 pp. Published by Elsevier Ltd.

Boiko S. M. 2015. Allozyme polymorphism in mono- and dikaryotic cultures of fungus Schizophyllum commune Fr. (Basidiomycetes). Cytology and Genetics 49: 27-31.

Bonde M. R., Micales J. A. \& Peterson G. L. 1993. The use of isozyme analysis for identification of plant-pathogenic fungi. Plant Disease 77: 961-968.

Bragaloni M., Anselmi N. \& Cellerino G. P. 1997. Identification of European Armillaria species by analysis of isozyme profiles. European Journal of Forest Pathology 27: 147-157.

Eichlerova I., Homolka L., Zifcakova L., Lisa L., Dobiasova P. \& BALDRIAN P. 2015. Enzymatic systems involved in decomposition reflects the ecology and taxonomy of saprotrophic fungi. Fungal ecology 13: 10-22.

Engh I. B., Carlsen T., Kauserud H., Hogberg N., Saetre G.-P. \& Dor S. 2010. Two invasive populations of the dry rot fungus Serpula lacrymans show divergent population genetic structures. Mol. Ecol. 19: 706-715.

Gorova T. L. 1980. Macromycetes derivatives spruce Ukrainian Carpathians. Ukr. Bot. J. 37: 44-50 (in Ukraine with English summary).

Grand L. F., Vernia C. S. \& Munster M. J. 2009. Biogeography and hosts of poroid wood decay fungi in North Carolina: species of Trametes and Trichaptum. Mycotaxon 106: 243-246.

Hames B. D. 1998. Gel Electrophoresis of Proteins: A Practical Approach 3rd ed. 352 pp. Oxford University Press, New York.

Hogberg N, Holdenreider O. \& Stenlid J. 1999. Population structure of the wood decay fungus Fomitopsis pinicola. Heredity 83: 354-360.

Huang H., Dane F. \& Kubisiak T. 1998. Allozyme and RAPD analysis of the genetic diversity and geographic variation in wild populations of the American chestnut (Fagaceae). Am. J. Bot. 85: 1013-1021.

James T. Y., Porter D., Hamrick J. L. \& Vilgalys R. 1999. Evidence for limited intercontinental gene flow in the cosmopolitan mushroom Schizophyllum commune. Evolution 53: 1665-1677.

Jasalavich C. A., Ostrofsky A. \& Jellison J. 2000. Detection and identification of decay fungi in spruce wood by restriction fragment length polymorphism analysis of amplified genes encoding rRNA. Applied and environmental microbiology 66: 4725-4734.

Kauserud H. \& Schumacher T. 2003a. Ribosomal DNA variation, recombination and inheritance in the basidiomycete Trichaptum abietinum: implications for reticulate evolution. Heredity 91: 163-172.

Kauserud H. \& Schumacher T. 2003b. Regional and local population structure of the pioneer wood-decay fungus Trichaptum abietinum. Mycologia 95: 416-425.

MAnchenko G. P. 2003. Handbook of detection of enzymes on electrophoretic gels. 553 pp. CRC Press.

Mishra A. K., Sharma K. \& Misra R. S. 2010. Isozyme and PCR-based genotyping of epidemic Phytophthora colocasiae associated with taro leaf blight. Archives of Phytopathology and Plant Protection 43: 1367-1380.

Mondini L., Noorani A. \& Pagnotta M. 2009. Assessing plant genetic diversity by molecular tools. Diversity 1: 19-35.

NeI M. 1978. Estimation of average heterozygosity and genetic distance from a small number of individuals. Genetics 89: 583-590.

Osono T. \& TAKeda H. 2006. Fungal decomposition of Abies needle and Betula leaf litter. Mycologia 98: 172-179.

Otieno O. D., Onyango C., Onguso J. M., Matasyoh L. G., Wanjala B. W., Wamalwa M. \& Harvey J. J. 2015. Genetic diversity of Kenyan native oyster mushroom (Pleurotus). Mycologia 107: 32-38.

Ovaskainen O., Schigel D., Ali-Kovero H., Auvinen P., Paulin L., Norden B. \& Norden J. 2013. Combining high-throughput sequencing with fruit body surveys reveals contrasting life-history strategies in fungi. ISME Journal 7: 1696-1709.

Runnel K., TAmm H. \& Lohmus A. 2015. Surveying woodinhabiting fungi: Most molecularly detected polypore species form fruit-bodies within short distances. Fungal Ecology 18: 93-99.

Shnyreva A. V. Belokon Yu. S., Belokon M. M. \& Altukhov YU. P. 2004. Interspecific genetic variability of the Oyster mushroom Pleurotus ostreatus as revealed by allozyme gene analysis. Russian Journal of Genetics 40: 871-881.

Siddiquee S., Abdullah F., Guan T. S. \& Rohaza E. 2007. Level in allozyme variations of Malaysian isolates of Trichoderma harzianum and its taxonomic implications. Research journal of microbiology 10 : 717-726.

Siddiquee S., Guan T. S. \& Kalsom Y. 2010. Isozyme analysis and relationships among three species in Malaysian Trichoderma isolates. J. Microbiol. Biotechnol 20: 1266-1275.

Stenlid J., Karlsson J. O \& Hogberg N. 1994. Intraspecific genetic variation in Heterobasidion annosum revealed by amplification of minisatellite DNA. Mycol. Res. 98: 57-63. 
Udu-Ibiam O. E., Ogbu O., Ibiam U. A., Nnachi A. U., Agah M. V., Ukaegbu C. O., Chukwu O.S., Agumah N. B. \& OgBu K. I. 2014. Phytochemical and antioxidant analyses of selected edible mushrooms, ginger and garlic from Ebonyi State, Nigeria. IOSR Journal of Pharmacy and Biological Sciences 9: 86-91.

XIN QIAN, CAI-XIA Wang \& Min Tian. 2013. Genetic diversity and population differentiation of Calanthe tsoongiana, a rare and endemic orchid in China. Int. J. Mol. Sci. 14: 20399-20413.

Yeh F. C., Yang R. \& Boyle T. 1999. POPGENE Version 1.32. Microsoft window-based freeware for population genetic analysis. Univ. Alberta. Center Intern. Forestry Res. ZJAWIONY J. K. 2004. Biologically active compounds from Aphyllophorales (Polypore) fungi. J. Nat. Prod. 67: 300-310. 